These kinds of mutations have been described for different colon, liver, prostate, ovarian and endometrial neoplasms [7], but not yet in BCC.

Disclosure. Financial support: This work was funded by IRBLLEIDA (R. Aguayo), the Ministry of Education and Science of Spain BFU2010-20293 (E. Garí), and Catalan Government SGR559 (E. Garí). RMH Fernández was supported by predoctoral fellowship from Ministry of Education and Science of Spain. Conflict of interest: none.

${ }^{1}$ Institut de Recerca Biomèdica de
Lleida,
${ }^{2}$ Department of Basic Medical
Sciences,
${ }^{3}$ Department of medicine,
Universitat de Lleida,
Av/Rovira Roure, $\mathrm{n}^{\circ} 80$,
25198, Lleida, Catalonia, Spain
${ }^{4}$ Department of dermatology,
Hospital Universitari Arnau de
Vilanova,
Lleida, Catalonia, Spain
$<$ raguayo@comll.cat>
<rafalleida@ @hotmail.com>

Rafael S. AGUAYO
Marta RAFEL
RAT $^{1,2}$
Maria SANTACANA
Rita MH. $^{1}$
FERNÁNDEZ
1,2
Verònica SANMARTÍN
Josep M. $^{4}$
CASANOVA
Eloi GARI $^{1,4}$

1. Bonifas JM, Pennypacker S, Chuang PT, et al. Activation of expression of hedgehog target genes in basal cell carcinomas. J Invest Dermatol 2001; 116: 739-42.

2. Ghali L, Wong ST, Green J, Tidman N, Quinn AG. Gli1 protein is expressed in basal cell carcinomas, outer root sheath keratinocytes and a subpopulation of mesenchymal cells in normal human skin. $J$ Invest Dermatol 1999; 1 13:595-9.

3. Saldanha G, Ghura V, Potter L, Fletcher A. Nuclear beta-catenin in basal cell carcinoma correlates with increased proliferation. $\mathrm{Br} \mathrm{J}$ Dermatol 2004; 151 : 157-64.

4. El-Bahrawy $M$, El-Masry $N$, Alison $M$, Poulsom R, Fallowfield $M$. Expression of beta-catenin in basal cell carcinoma. $\mathrm{Br} J$ Dermatol 2003; 148: 964-70.

5. Yang SH, Andl T, Grachtchouk V, et al. Pathological responses to oncogenic Hedgehog signaling in skin are dependent on canonical Wnt/beta3-catenin signaling. Nat Genet 2008; 40: 1130-5.

6. Staibano S, Lo Muzio L, Pannone G, et al. DNA ploidy and cyclin D1 expression in basal cell carcinoma of the head and neck. Am J Clin Pathol 2001; 115: 805-13.

7. Doglioni C, Piccinin S, Demontis S, et al. Alterations of beta-catenin pathway in non-melanoma skin tumors: loss of alpha- $A B C$ nuclear reactivity correlates with the presence of beta-catenin gene mutation. $\mathrm{Am} \mathrm{J}$ Pathol 2003; 163: 2277-87.

doi:10.1684/ejd.2013.2130

\section{Acquired bilateral nevoid telangiectasia: report of 9 cases}

Unilateral nevoid telangiectasia (UNT), a superficial telangiectasia usually of the upper body, shows a unilateral dermatomal distribution, typically in the $\mathrm{C} 3$ to $\mathrm{T} 3$ dermatomes. The exact cause is unknown, but it is speculated to be associated with hyperestrogenic states, owing to the high prevalence of puberty, pregnancy and liver diseases in affected patients [1-5], together with an increase of estrogen receptors in a dermatomal distribution $[2,6]$. The correlation between estrogen and UNT is questioned due to lack of serum evidence in non-pregnant patients. Approximately a hundred cases have been described to date but only two with its peculiar variant, bilateral nevoid telangiectasia (BNT) $[7,8]$. BNT is analogous to UNT in that, although bilateral in its presentation, it follows the characteristic dermatomal distribution of the typically 'spider' telangiectasias. Our knowledge of this particular bilateral variant is limited. We report nine patients with BNT to shed further light on this atypical variant of UNT.

Prior to the diagnosis of BNT, hereditary hemorrhagic telangiectasia and generalized essential telangiectasia were ruled out via evidence including negative family history or history of spontaneous epistaxis and differences in morphology and distribution $[9,10]$. Histopathology in all cases revealed numerous thin-walled dilated vessels in the superficial dermis with a normal epidermis, and toluidine blue staining confirmed the lack of mast cells, making telangiectasia macularis eruptiva perstans improbable. Table 1 demonstrates the general characteristics of our patients and the two previously reported cases.

Of the nine patients, six were men and three were women (male:female ratio, 2:1). Mean age was 47.9 years (range 30-60) and all the patients had a disease onset after the age of 18 years (mean age of onset, 42).

Telangiectatic lesions in all nine patients showed symmetrical distribution, both covering and sparing the same dermatomes on each side of the body. The lesions, predominantly 'spider' in morphology, showed symmetrical involvement of the arms in all nine patients. Only patients 6 and 9 presented with lesions also involving the upper trunk, showing a 'checkerboard' pattern. Lesions were observed to coalesce in the midline when involving the neck, while interrupted at the midline when involving the trunk.

Whilst the otherwise unexplained gastrointestinal (GI) involvement was emphasized in both previously reported cases [7, 8], only one of two patients showing GI involvement (gastric telangiectasia) had no underlying pathologic condition (patient 2). Esophagogastroduodenoscopy (EGD) was not routinely recommended at the time of presentation and patients 2 and 9 had incidentally performed the procedure due to epigastric discomfort and pre-diagnosed cholangiocarcinoma with intrahepatic metastasis, respectively. Previous annual EGD check-ups in patients $1,4,5$, and 7 revealed no abnormal findings. This shows that GI involvement without underlying liver dysfunction may not be a principle trait of BNT. Although serum hormone levels were not specifically checked in our patients, the preceding discordance between the two previously reported cases continues to exist; only patients 6 and 9 had liver conditions that may possibly induce a hyperestrogenic state.

Another remarkable observation is the difference in the extent of cutaneous involvement in association with hostile liver conditions. Telangiectasias on patients 6 and 9, who had underlying chronic C-viral hepatitis and intrahepatic metastasis of cholangiocarcinoma, respectively, were more extensive, involving a greater number of dermatomes. While only the upper extremities were involved in the other seven patients, the two patients with liver dysfunctions had lesions that also involved the upper trunk. Whether this supports the previous theory of estrogen influence or is the consequence of various degrees of possi- 
Table 1. Patient characteristics, underlying co-morbidities, and laboratory tests at the time of presentation. Hormone levels were not checked in the above nine patients.

\begin{tabular}{|c|c|c|c|c|c|c|c|}
\hline Patient No. & Gender & Age & $\begin{array}{l}\text { Underlying } \\
\text { physiologic } \\
\text { condition }\end{array}$ & $\begin{array}{l}\text { Underlying/ } \\
\text { Concurrent } \\
\text { pathologic } \\
\text { condition }\end{array}$ & $\begin{array}{l}\text { Laboratory and } \\
\text { endoscopy } \\
\text { findings }\end{array}$ & $\begin{array}{l}\text { Dermatomal } \\
\text { distribution }\end{array}$ & $\begin{array}{l}\text { Type of } \\
\text { telangiectasia }\end{array}$ \\
\hline 1 & $\mathrm{~F}$ & 52 & $\mathrm{x}$ & $\begin{array}{l}\text { Hypertension } \\
\text { Behcet's disease }\end{array}$ & Normal & Bilateral C5-6 & Spider \\
\hline 2 & M & 54 & $\mathrm{x}$ & $\mathrm{x}$ & $\begin{array}{l}\text { EGD - gastric } \\
\text { telangiecta- } \\
\text { sia/bleeding }\end{array}$ & Bilateral C5-6 & Spider \\
\hline 3 & $\mathrm{~F}$ & 35 & $\mathrm{x}$ & $\mathrm{x}$ & Normal & Bilateral C6-7 & Spider \\
\hline 4 & M & 51 & $\mathrm{x}$ & $\mathrm{x}$ & Normal & Bilateral C4-6 & Spider \\
\hline 5 & $\mathrm{~F}$ & 46 & $\mathrm{x}$ & $\mathrm{x}$ & Normal & Bilateral C6-8 & Spider \\
\hline 6 & M & 40 & $\mathrm{x}$ & $\begin{array}{l}\text { Chronic hepatitis } \\
\text { C }\end{array}$ & $\begin{array}{l}\text { Elevated OT/PT } \\
(26 / 61) \\
\text { elevated } \\
\text { gamma-GT (72) }\end{array}$ & $\begin{array}{l}\text { bilateral C7-8 } \\
\text { upper chest } \\
(\mathrm{T} 2-3)\end{array}$ & Spider \\
\hline 7 & M & 60 & $\mathrm{x}$ & Hypertension & Normal & Bilateral C5-6 & Spider \\
\hline 8 & M & 30 & $\mathrm{x}$ & $\mathrm{x}$ & Normal & Bilateral C5-6 & Spider \\
\hline 9 & M & 54 & $\mathrm{x}$ & $\begin{array}{l}\text { Cholangiocarcinoma } \\
\text { (intrahepatic and } \\
\text { lung metastasis) }\end{array}$ & $\begin{array}{l}\text { Lab not } \\
\text { performed } \\
\text { EGD - gastric } \\
\text { erosion with } \\
\text { telangiectasia }\end{array}$ & Bilateral C3-T12 & Spider \\
\hline 1 (Tang et. al) & $\mathrm{F}$ & 33 & $\begin{array}{l}\text { Pregnancy } \\
\text { state } \\
\text { IUP } 23 \text { wks }\end{array}$ & $\mathrm{x}$ & $\begin{array}{l}\text { Elevated } \\
\text { E2/progesterone } \\
(1835,1240) \\
\text { EGD - gastric } \\
\text { telangiecta- } \\
\text { sia/bleeding }\end{array}$ & Bilateral C3-T3 & Spider \\
\hline 1(Turan et. al) & M & 27 & $\mathrm{x}$ & $\mathrm{x}$ & $\begin{array}{l}\text { EGD - duodenal } \\
\text { telangiectasia }\end{array}$ & $\begin{array}{l}\text { Bilateral C2 \& } \\
\text { T3 }\end{array}$ & Spider/wiry \\
\hline
\end{tabular}

bly concurrent portal hypertension is not known, but it may indicate a closer examination of liver function in patients who present with such involvement of the dermatomes. Despite similarities in morphology and distribution, dissimilarities exist between reported UNT patients and our BNT patients. Unlike in UNT, the majority of our patients were male. Furthermore, none was going through puberty or pregnant. Only two cases showed underlying liver conditions which may alter serum estrogen levels. Even more interesting, two patients $\left(\mathrm{N}^{\circ} 1\right.$ and 5)were approximately one year post-menopause.

This rarely reported disease may not actually be a rare condition but only under-diagnosed or under-reported. With our nine cases, however, we offer a stepping stone to a better understanding of this enigmatic disease.

Disclosure. Financial support: none. Conflict of interest: none.

Department of Dermatology,

Yonsei University College of

Medicine

134 Shinchon-Dong,

Seodaemoon-Gu,

Seoul 120-752, Korea

<mglee@yuhs.ac>
1. Aram H, Solomon LM. Linear telangiectasia. Acta Derm Venereol 1970; 50: 302-8.

2. Wilkin JK, Smith JG Jr., Cullison DA, et al. Unilateral dermatomal superficial telangiectasia. Nine new cases and a review of unilateral dermatomal superficial telangiectasia. J Am Acad Dermatol 1983; 8: 468-77.

3. Mirrer E, Cipriano A, McGuire J. Unilateral nevoid telangiectasia. Arch Dermatol 1971; 103: 320-3.

4. Anderton RL, Smith JG Jr.. Unilateral nevoid telangiectasia with gastric involvement. Arch Dermatol 1975; 111:617-21.

5. Capron JP, Kantor G, Dupas JL, et al. Unilateral nevoid telangiectasia and chronic liver disease. Report of a case and review of the literature. Am J Gastroenterol 1981;76: 47-51.

6. Uhlin SR, McCarty KS Jr.. Unilateral nevoid telangiectatic syndrome. The role of estrogen and progesterone receptors. Arch Dermatol 1983; 119:226-8.

7. Tang SJ, Faughnan ME, Marcon NE. Bilateral nevoid telangiectasia syndrome. Gastrointest Endosc 2004; 60: 468-71.

8. Turan $A$, Saricaoglu $H$, Bulbul Baskan $E$, et al. Acquired bilateral nevoid telangiectasia syndrome with gastrointestinal involvement. Eur J Dermatol 2011; 21:629-30.

9. Shovlin CL, Guttmacher AE, Buscarini E, et al. Diagnostic criteria for hereditary hemorrhagic telangiectasia (Rendu-Osler-Weber syndrome). Am J Med Genet 2000; 91:66-7.

10. Checketts SR, Burton PS, Bjorkman DJ, et al. Generalized essential telangiectasia in the presence of gastrointestinal bleeding. J Am Acad Dermatol 1997; 37: 321-5.

doi:10.1684/ejd.2013.2141 